๑RDINES MILITARES

COLLOQUIA TORUNENSIA HISTORICA

Yearbook for the Study of the Military Orders

ISSN (print) 0867-2008 / ISSN (online) 2391-7512

DOI: http://dx.doi.org/10.12775/OM.2015.011

\title{
Aleksander Pluskowski, The Archaeology of the Prussian Crusade: Holy War and Colonisation, Routledge, Abingdon 2013, xix +428 pp. + illustrations and maps, ISBN 978-0-4I 5-6917I-0.
}

This work consists of eight thematic chapters and an extensive summary at the end. The introduction starts by explaining terminology, particularly the author's use of historic and modern placenames as well as names of selected medieval administrative units and ranks within the Teutonic Order. The second part of the introduction provides a survey of literature including relevant historical sources as well as archaeological data and interdisciplinary studies. It is worth noting that there are two mistakes in this section. First, contrary to the author's assertion, there is no Polish edition of the 'Chronicle' written by Simon Grunau (pp. 25-26); the work by Sławomir Zonenberg to which the author refers as the Polish edition of this 'Chronicle' provides only an analysis of the text with discussion of the context in which it was written. ${ }^{\mathrm{I}}$ The second mistake concerns the dating of the bog body from Drwęck (Ger. Dröbnitz). The body of a woman discovered there in 1939 dates most likely from the early Iron Age and not, as the author asserts, from the i 9 th century. This error most probably results from inaccurate reading of the article by Mirosław J. Hoffmann. ${ }^{2}$

After the introduction, the author focuses on the history and culture of pre-Christian Prussia. Drawing predominantly on archaeological data and making little use of historical sources, the discussion treats the tribal organisation of Prussia and describes a wide selection of archaeological sites, particularly strongholds and burial grounds. Some of the references, however, are inaccurate. For example, the fragment of an early medieval wooden chest (p. 52) was discovered at the stronghold at Lake Silm near Kamionka (Ger. Klein Steinersdorf) 3 , not at the stronghold at Susz (Ger. Rosenberg). ${ }^{4}$ Another mistake is the assertion that the Arabic coin discovered in the stronghold on an island in Lake Slim dates from

1 S. Zonenberg, Kronika Szymona Gruanaua, Bydgoszcz 2009.

2 M. J. Hoffmann, $Z$ historii badań archeologicznych $w$ rejonie pól grunwaldzkich, in: Tradycje kulturowe $i$ historyczne ziem pruskich. Krajobraz grunwaldzki w dziejach polsko-krzyżackich i polsko-niemieckich na przestrzeni wieków. Wokót mitów i rzeczywistości, ed. J. Gancewski, Olsztyn 2009, pp. 146-149.

3 W. Łęga, Kultura Pomorza we wczesnym średniowieczu na podstawie wykopalisk (Roczniki Towarzystwa Naukowego w Toruniu 35), Toruń 1929, pp. 409, 428, tab. LXVIII, fig. 442.

4 Ł. Okulicz-Kozaryn, Życie codzienne Prusów i Jaćwięgów w wiekach średnich (IX-XIII w.), Warszawa 1983, p. 111.

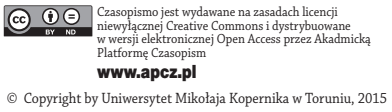


the I I th century (p. 54).5 In fact there are no Arab coins dating from that period in Prussia; the archaeological report on the site from 1908 records the discovery of a 'half of a well preserved kufic coin made of silver' without providing its date. ${ }^{6}$

The following section of the book discusses craft production in Prussia, regional trade contacts and war. Much attention is also devoted to the attempted characterisation of the Prussian religion. The analysis includes discussion of carved stone figures known as baby pruskie (pp. 7I-75) to which the author inaccurately translates as 'stone women'. The term $b a b a$ may refer to a woman in Polish but the word originally comes from Turkic languages in which baba or bal-bal can be understood as meaning 'ancestor' or 'warrior' and has nothing to do with women. ${ }^{7}$ Pluskowski is not aware of this and thus wrongly argues that it is likely that the carved stone figures are representations of goddesses or Valkyries, even though many of the figures are depicted with beards and moustaches! Furthermore, there are almost 80 'offering stones' recorded in Prussia, not 15 as the author states. ${ }^{8}$ In the analysis of burial rituals, the narrative from the chronicle of Nicholas von Jeroshin concerning the alleged burning of the wife of a deceased nobleman on a pyre is inaccurately translated (p. 78). The chronicle refers to a servant of the nobleman (meide), not his wife. 'The third chapter focuses on the conquest of Prussia while the fourth discusses the regional administrative divisions introduced by the Teutonic Order and the consolidation of his power in the Baltic region. The titles of the Order's offices are often translated into English, sometimes accompanied by a brief description, although the English equivalent of Kammerämter, that is bailiwicks, is missing (p. I 42 ).

In the next chapter the author describes the process of urbanisation and the place of the Prussian cities in the international trade network. Chapter six focuses on the process of Christianisation and the preservation of pagan customs among the indigenous Prussian population. One cannot agree with the author, however,

5 W. Skrobot, Osadnictwo wczesnośredniowieczne w strefach pogranicznych Pojezierza Itawskiego, in: Pruskie baby kamienne. Fenomen kulturowy czy europejska codzienność?, ed. J. M. Łapo, G. Białuński, Olsztyn 2007, p. 119.

6 This report is copied from a transcript by Waldemar Heym preserved in the Archive of the Archaeological Museum in Gdańsk: MAG, Silma, sygn. 46n/27, and appears in the article W. Heym, Siedlungsgrabungen im Kreise Rosenberg, Heimatkalender der Kreis Rosenberg 1933, p. 58.

7 W. Demetrykiewicz, Figury kamienne t.zw. "bab” w Azyi i Europie i stosunek ich do mitologii stowiańskiej. (Altertümliche steinere Statuen, sog. „baby" [Steinmüterchen, Becherstatuen] und ihr Verbältnis zur slavischen Mythologie), Bulletin International de L'Académie des Scienscs de Cracovie. Classe de Philologie. Classe d'Historie et de Philosophie, Cracovie 1910, p. 101.

8 R. Klimek, Kamienie kultowe na ziemiach pruskich, in: Kamienie $w$ historii, kulturze i religii, ed. R. Klimek, S. Szczepański, Olsztyn 2010, pp. 62-109.

9 Di Kronike von Pruzinlant des Nicolas v. Jeroschin, hrsg. v. E. Strehlke, Scriptores rerum Prussicarum, Bd. I, Leipzig 1861, v. 4069-4076, p. 349. 
that the list of churches mentioned in the Treaty of Christburg ( I 249) refers only to sites that were to be reconstructed after being destroyed during the Prussian uprising (p. 252). Many of these churches were constructed on sites where there were no Christian shrines before. The treaty specifically notes the 'building' (edificabunt) of churches in Pomesania, Warmia and Natangia in order to ensure that recently converted Christians in those regions had access to religious services. It is also not true that the listed churches were built near the Teutonic Order's strongholds ( $\mathrm{p}$. 252); many were constructed within existing Prussian settlements or as part of newly developing sites. ${ }^{10}$ The key part of the book is undoubtedly chapter seven (co-authored by Alex Brown) which provides a detailed account of the changes in the natural environment of medieval Prussia. The analysis is based predominantly on palaeobotanical and zooarchaeological data.

In the final chapter the author focuses on the decline of the crusader ideology in Prussia and the challenges faced by the Teutonic Order after the Christianisation of Lithuania and its alliance with Poland. Particular attention is paid to the analysis of the transition from waging a holy war against pagans to a secular conflict between Christian powers. The study, however, includes some chronological and factual errors; for example Pluskowski claims that Vytautas and Jagiełło were brothers (p. 337), whereas in fact they were cousins. Also, the dates given for the military conflict between the Polish King Stephen Bathory and Gdańsk (Ger. Danzig) are inaccurate; the war took place in I 576-I 577 , not I $577-1588$ (p. 361).

In summary, The Archaeology of the Prussian Crusade is a well written synthesis of the history of medieval Prussia. Unfortunately in a number of cases Pluskowski inaccurately interprets materials that were presented to him or copies information without critical assessment. Primary sources are not always translated appropriately and there are some mistakes in the spelling of local place names and offices, for instance 'kumornictwo' instead of komornictwo, 'Zalewa' instead of Zalewo, 'Kalwie' instead of Kalwa or Julian 'Urzyn' Niemcewicz instead of Julian Ursyn Niemcewicz. The structure of the book is also not always clear. Sometimes the same theme is analysed in different chapters and discussion is left without a conclusion only to return later. Nonetheless, despite these weaknesses, the book is a valuable source of information for an English-speaking reader interested in the history of the Prussians and the Teutonic Order.

Seweryn Szczepański (Olsztyn)

10 R. Wenskus, Über die Bedeutung des Christburger Vertrages für die Rechts- und Verfassungsgeschichte des Preussenlandes, in: Studien zur Geschichte des Preussenlandes, Marburg 1963, pp. 97-118; S. Szczepański, Chomor sancti Adalberti (1249) a możliwości lokalizacji terenowej wybranych kościotów Pomezanii, Komunikaty Mazursko-Warmińskie 2013, 1 (279), pp. 19-45. 


\title{
○RDINES MILITARES COLLOQUIA TORUNENSIA HISTORICA Yearbook for the Study of the Military Orders
}

\author{
vol. XX (2015)
}


EDITORIAL BOARD

Roman Czaja, Editor in Chief, Nicolaus Copernicus University Toruń

Jürgen Sarnowsky, Editor in Chief, University of Hamburg

Jochen Burgtorf, California State University

Sylvain Gouguenheim, Ecole Normale Supérieure Lettres et Sciences Humaines de Lyon Hubert Houben, Università del Salento Lecce

Alan V. Murray, University of Leeds

Krzysztof Kwiatkowski, Assistant Editor, Nicolaus Copernicus University Toruń

REVIEWERS:

Udo Arnold, Rheinische Friedrich-Wilhelms-Universität Bonn (retired)

Jochen Burgtorf, Department of History, California State University

Marian Dygo, Instytut Historyczny, Uniwesytet Warszawski Alan Forey, Durham University (retired)

Mateusz Goliński, Instytut Historyczny, Uniwersytet Wrocławski

Sylvain Gouguenheim, Ecole Normale Supérieure Lettres et Sciences Humaines de Lyon

Dieter Heckmann, Geheimes Staatsarchiv Preußischer Kulturbesitz, Berlin-Dahlem

Heinz-Dieter Heimann, Universität Potsdam (retired)

Hubert Houben, Dipartimento di Storia, Società e Studi sull'uomo, Universita del Salento, Lecce

Sławomir Jóźwiak, Instytut Historii i Archiwistyki, Uniwersytet Mikołaja Kopernika, Toruń

Tomasz Jurek, Instytut Historii im. Tadeusza Manteuffla Polskiej Akademii Nauk, Warszawa

Waldemar Könighaus, Akademie der Wissenschaften zu Göttingen

Ilgvars Misāns, Faculty of History and Philosophy, University of Latvia, Riga Helen Nicholson, History Department, Cardiff University

Jürgen Sarnowsky, Fakultät für Geisteswissenschaften, Universität Hamburg

Kristjan Toomaspoeg, Beni Culturali Department, Università Del Salento, Lecce

Address of Editorial OfFice:

Instytut Historii i Archiwistyki UMK, ul. Władysława Bojarskiego 1

87-100 Toruń

e-mail: rc@umk.p

juergen.sarnowsky@uni-hamburg.de

Subscriptions orders shoud be addressed to:

$$
\text { books@umk.pl }
$$

creative

Czasopismo jest wydawane na zasadach licencji niewyłącznej

Creative Commons i dystrybuowane w wersii elektronicznej

Open Access przez Akadmicką Platformę Czasopism (c) (1)

www.apcz.pl

Printed in Poland

(C) Copyright by Uniwersytet Mikołaja Kopernika w Toruniu and Towarzystwo Naukowe w Toruniu Toruń 2015

ISSN $0867-2008$

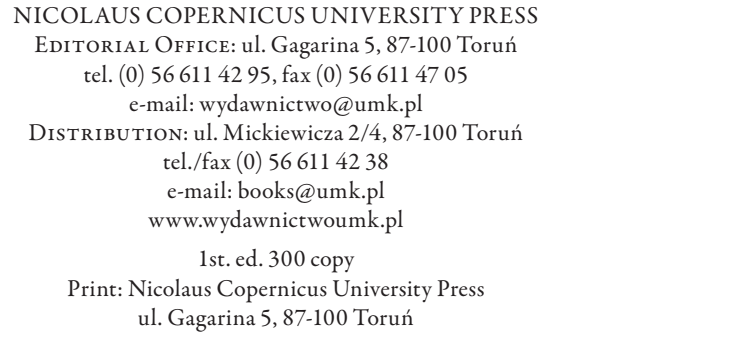




\section{CONTENTS}

\section{STUDIES AND ARTICLES FROM THE $17^{\text {TH }}$ ORDINES MILITARES CONFERENCE}

Alan V.Murray (Leeds)

The Grand Designs of Gilbert of Assailly. The Order of the Hospital in the Projected Conquest of Egypt by King Amalric of Jerusalem (I 168 - I 169 ) ...

Karl Borchardt (München)

Die Templer an der römischen Kurie im I 3. Jahrhundert: ein Netzwerk? ......

Marie-Luise Favreau-Lilie (Berlin)

Der Deutsche Orden in Norditalien (1 3. Jh.). Über die Grenzen der

"Netzwerkforschung"

Christian Gablbeck (Berlin)

Adlige Netzwerke in der mittelalterlichen Ballei Brandenburg des

Johanniterordens

Maria Starnawska (Częstochowa)

Karrieren innerhalb des Johanniterordens (in den schlesischen ländlichen Kommenden des böhmischen Priorats) als Bestandteil familierer Strategien des Rittertums

Johannes A. Mol (Leiden)

The knight brothers from the Low Countries in the conflict between the Westphalians and the Rhinelanders in the Livonian branch of the Teutonic Order

Bernhard Demel (Wien)

Zur Reichspolitik des livländischen Ordenszweiges in den Jahren I $52 \mathrm{I}$ bis I56I/I 562 


\section{OTHER STUDIES}

\section{Loüc Chollet (Neuchâtel)}

Croisade ou évangélisation? La polémique contre les Chevaliers

Teutoniques à l'aune des témoignages des voyageurs français de la fin du Moyen-Âge

Anette Löffler (Frankfurt/Main)

Swester und Oberste - ein Brevier für einen Schwesternkonvent des

Deutschen Ordens

Stawomir Jóźwiak (Toruń), Janusz Trupinda (Gdańsk)

Das Amt des „Bauleiters“ (magister lapidum; magister laterum;

steinmeister; czygelmeyster; muwermeister) im Deutschordensstaat im

I 4. Jh. und in der ersten Hälfte des I 5 . Jh.

\section{BOOK REVIEWS AND BOOK NOTES}

Aleksander G. Pluskowski, The Archaeology of the Prussian Crusade: Holy War and Colonisation (by Seweryn Szczepanski)

Marc Sgonina, Die Johanniterballei Westfalen. Unter besonderer Berücksichtigung der Lebensformen der Zentralkommende Steinfurt und ihrer Membra (by Christian Gablbeck)

Jerusalem in the North: Denmark and the Baltic Crusades, II0o-I522, eds. Ane Bysted, Carsten V. Jensen, Kurt S. Jensen, John Lind (by Roman Czaja)

Alain Demurger, La persécution des Templiers. Journal (1307-1314)

(by Magdalena Satora)

Tous les diables d'enfer. Rélations du siège de Rhodes par les Ottomans en I480, ed. Jean-Bernard de Vaivre, Laurent Vissière (by Jürgen Sarnowsky)

Generalprobe Burzenland. Neue Forschungen zur Geschichte des Deutschen Ordens in Siebenbürgen und im Banat, hrsg. v. Konrad Gündisch

(by Krzysztof Kwiatkowski)

Die Hochmeister des Deutschen Ordens IIgo-2012, hrsg. v. Udo Arnold

(by Krzysztof Kwiatkowski)

Beztawki - ocalić od zniszczenia. Wyniki prac interdyscyplinarnych prowadzonych w latach 2008-20II, red. Arkadiusz Koperkiewicz (by Krzysztof Kwiatkowski)

Das „virtuelle Archiv des Deutschen Ordens“, hrsg. v. Maria M. Rückert

(by Radostaw Biskup) 